A RCHIWA, BIBLIOTEKI

I MUZEA KOŚCIELNE 112 (2019)

https://doi.org.10.31743/abmk.2019.112.04

KS. GRZEGORZ BUJAK* - LUBLIN

\title{
DUCHOWIEŃSTWO KATOLICKIE WOBEC ZMIAN SPOŁECZNYCH W OKRESIE MIECZYWOJENNYM. ZARYS PROBLEMATYKI BADAWCZEJ
}

\begin{abstract}
Streszczenie
W artykule zostały zaprezentowane charakterystyczne dla duchowieństwa katolickiego okresu międzywojennego poglądy na wybrane aspekty zmian zachodzących w społeczeństwie polskim w tamtym czasie dotyczących religijności, obyczajowości, rodziny i wychowania młodego pokolenia. Analiza ma charakter wstępny i sondażowy. Omówione w niej zostały jedynie niektóre aspekty dotyczące tej problematyki, ukazane w kontekście międzywojennych prądów odnowy katolicyzmu. Podstawę źródłową stanowią wypowiedzi duchownych, głównie $\mathrm{z}$ dwóch dawnych zaborów pruskiego i rosyjskiego, zawarte na łamach dwóch wpływowych i opiniotwórczych w tych środowiskach miesięczników: poznańskich „Wiadomości dla Duchowieństwa” i wychodzących w Warszawie „Wiadomości Archidiecezjalnych Warszawskich”.

Słowa kluczowe: Kościół katolicki; duchowieństwo; okres międzywojenny; II Rzeczpospolita; zmiany społeczne
\end{abstract}

Pierwsza wojna światowa stanowiła ważny przełom w dziejach społeczeństw europejskich. Dotyczyło to również terenów wschodniej Europy, gdzie dokonał się spektakularny upadek trzech wielkich potęg imperialnych i powstanie na ich gruzach licznych, dość słabych, organizmów państwowych. Dotyczyło to także odrodzonej Polski, w której skład weszły duże odłamy społeczeństw dawnych imperiów niemieckiego, austriackiego i rosyjskiego o odmiennych drogach rozwoju, zróżnicowane wewnętrznie pod względem narodowościowym, ale co ważniejsze kulturowym i cywilizacyjnym.

Ważną cechą odradzającego się po 1918 r. społeczeństwa, był silny i masowy związek tworzących je grup narodowościowych z ich tradycyjnymi religiami. Do-

* Ks. Grzegorz Bujak - dr hab. historii; adiunkt w Instytucie Historii Katolickiego Uniwersytetu Lubelskiego Jana Pawła II; e-mail: gbujak@kul.pl

https://orcid.org/0000-0003-2298-2757 
tyczyło to nie tylko związanej głównie z katolicyzmem większości polskiej, ale także mniejszości etnicznych i grup narodowościowych tworzących międzywojenne społeczeństwo polskie. Rzymscy-katolicy stanowili ok. 65\% społeczeństwa $i$ była to grupa wewnętrznie ogromnie zróżnicowana ${ }^{1}$. Istotny wpływ na kształtowanie jej postaw, nie tylko religijnych ale i społecznych, wywierało liczne duchowieństwo. W skutek hierarchicznej struktury katolicyzmu i dodatkowo słabości świeckich elit religijnych, w okresie międzywojennym to w znacznej mierze na księżach spoczywała odpowiedzialność za to jak polski katolicyzm sprosta intelektualnemu i praktycznemu wyzwaniu jakim były ówczesne przemiany społeczne. Charakter tych przemian, ich kierunki a przede wszystkim tempo i masowość po I wojnie światowej, zmieniały niezwykle szybko i głęboko społeczeństwo II Rzeczpospolitej.

Tematem niniejszego artykułu będzie próba analizy wypowiedzi duchowieństwa w odniesieniu do kilku wybranych, ale niezwykle ważnych obszarów tych przemian: religijności, zmian obyczajowych, rodziny i wychowania młodego pokolenia. Mimo, że każdy z tych aspektów posiada obszerną literaturę szczegółową, to próba spojrzenia na zachodzące w tym zakresie przemiany jako konsekwencję intelektualnego zaplecza i stanu kapitału kulturowego polskiego katolicyzmu, nie doczekała się jak dotąd obszerniejszego opracowania ${ }^{2}$.

Artykuł jest jedynie próbą pokazania kilku głównych trendów w tym zakresie i ich wybranych skutków. Ma on charakter sondażowy. Z tego względu obejmie jedynie wspomniane cztery zagadnienia, a podstawą analizy będą wypowiedzi duchowieństwa, głównie z zaboru pruskiego i rosyjskiego, zawarte na łamach dwóch wpływowych i opiniotwórczych w tych środowiskach miesięczników: poznańskich „Wiadomości dla Duchowieństwa” (dalej: WDD) i wychodzących w Warszawie „Wiadomości Archidiecezjalnych Warszawskich” (dalej: WAW).

Wybór czasopism został podyktowany tym, że w gronie ich autorów znajdowali się duchowni znani i zaangażowani w działalność społeczną, w tym także aktualni, lub przyszli biskupi. Czasopisma wychodziły przez długi okres międzywojnia $^{3}$ i posiadały poparcie władz diecezjalnych dla pojawiających się na ich łamach wypowiedzi. Ich celem było propagowanie określonych poglądów i kształtowanie postaw głównie duchowieństwa diecezjalnego. Podejmowany na łamach obu miesięczników wysiłek opisania i zrozumienia zachodzących zmian społecznych oraz wskazania celów i działań tak duchowieństwa jak i świeckich

\footnotetext{
${ }^{1}$ Kościót katolicki w Polsce 1918-1990. Rocznik statystyczny, red. L. Adamczuk, W. Zdaniewicz, Warszawa 1991, s. 38.

${ }^{2}$ O. Bergmann, Pomiędzy konserwatywnym tradycjonalizmem a nowoczesnością. Bezpośredni i pośredni wplyw duchowieństwa katolickiego na procesy modernizacji spotecznej i gospodarczej Drugiej Rzeczypospolitej, w: Metamorfozy społeczne, t. 5. Religia a społeczeństwo Drugiej Rzeczypospolitej, red. T. Stegner, Warszawa 2013, s. 83-105.

${ }^{3}$ „Wiadomości Archidiecezjalne Warszawskie” wychodziły przez całe międzywojnie, a „Wiadomości dla Duchowieństwa" wychodziły co prawda tyko do roku 1933 (Bibliografia katolickich czasopism religijnych w Polsce 1918-1944, red. Z. Zieliński, Lublin 1981, s. 320-321), jednak dla ważnego z mojej perspektywy badawczej okresu ukazują wyraźną jeszcze wówczas specyfikę i odrębność tradycji intelektualnej duchowieństwa byłego zaboru pruskiego.
} 
w dziele realizacji katolickiego programu odnowy społeczeństwa, był jednym z niezwykle ważnych celów zamieszczanych tam wypowiedzi zarówno o charakterze prywatnym, jak i urzędowym.

Wraz z końcem pierwszej wojny światowej w wypowiedziach duchownych zamieszczanych na łamach odradzającej się prasy pojawiały się liczne wypowiedzi wskazujące, że jedną z jej ważnych konsekwencji był zanik wiary i pobożności wśród wiernych. Zmiany te wyraźnie dawały o sobie znać zarówno w środowiskach miejskich i wielkoprzemysłowych, jak i na wsi. Duszpasterz z Zagłębia Dąbrowskiego ks. W. Zamojski pisał jeszcze w 1917 r. „Trzeba to powiedzieć otwarcie, że obojętność religijna wśród ludności Zagłębia w czasie wojny znacznie wzrosła i czas zmiany na lepsze nie przynosi”4. Przedwojenna religijność, będąca przed rokiem 1914 również często przedmiotem krytyki duchowieństwa, ulegała idealizacji w porównaniu ze stanem powojennym. Zajmujący się tym zagadnieniem duchowny z poznańskiego ks. I. Adamski pisał:

Koniec wojny wszechświatowej przyniósł nam dwa wyniki: jeden niesłychanie radosny niepodległość naszej ojczyzny, drugi bezbrzeżnie smutny niesłychane zepsucie życia moralnego narodów. Wojna i jej skutki wstrząsnęły do gruntu społecznością ludzką (...). Powszechny ten wstrząs nie oszczędził także naszej wsi polskiej. Przywykli przed wojną do uregulowanej spokojnej pracy pastoralnej patrzyliśmy tuż po wojnie na tak złowrogi ferment wśród ludu naszego, że chwilami wydawało nam się, że wszystko ginie. (...) Osłabienie wiary to pierwszy fakt, który stwierdzamy po wojnie także w rodzinach wiejskich ${ }^{5}$.

W dalszych częściach swoich wypowiedzi autorzy analizowali przejawy tego osłabienia wiary i jako jeden z najważniejszych wskazywali mały udział wiernych w mszach św. i rzadsze przyjmowanie do komunii św. Cytowany ks. W. Zamojski odnotowywał dla Zagłębia Dąbrowskiego:

Nie było nigdy tylu ile jest dzisiaj wypadków śmierci bez posługi kapłańskiej, coraz mniej widzimy ludzi przy konfesjonałach, coraz mniej odbywa spowiedź wielkanocną, słowem z dnia na dzień wzrasta przyzwyczajenie do obywania się bez Kościoła i kapłana ${ }^{6}$.

Podobne stwierdzenia pojawiały się $\mathrm{w}$ wypowiedziach księży $\mathrm{z}$ poznańskiego. W sposób dosadny i typowy dla poglądów duszpasterzy kwitował to ks. F. Marlewski: „Człowiekowi nowoczesnemu nie chce się mieć duszy, bo bez niej wygodniej"'.

W zmieniającej się rzeczywistości społecznej księża widzieli poważną konkurencję dla tradycyjnych struktur wyznaczających dotychczas ramy życia wspólnoty wiernych:

Obok kościoła stanęły nowe świątynie. Świątynie pracy: fabryki; świątynie użycia i rozrywek: kawiarnie, kina, kabarety i dancingi; świątynie sportu: lot-

${ }^{4}$ W. Zamojski, Potrzeba czasu, „Przegląd Diecezjalny”, 5 (1917-1918) nr 1, s. 12.

${ }^{5}$ I. Adamski, Odrodzenie rodziny katolickiej w parafiach wiejskich, WDD, 13 (1926) $\mathrm{nr} 4$, s. $4-5$

${ }^{6}$ W. Zamojski, Potrzeba czasu, s. 12.

${ }^{7}$ F. Marlewski, Kazania w zastosowaniu do dzisiejszych czasów i prądów, WDD, 9 (1922) nr 12, s. 219. 
niska, igrzyska, turnieje, stadiony; świątynie Bachusa: restauracje, bary, karczmy, przypominające znane hasło upadającego cesarskiego Rzymu: panem et circenses. W niedziele i dni powszednie stale otwarte knajpy i domy zabaw wabią przechodnia i odbierają mu czas i ochotę do praktyk religijnych ${ }^{8}$.

Wśród wypowiedzi księży znajdujemy takie, w których porównywali oni sytuację w polskim społeczeństwie do przemian religijności w Europie Zachodniej. Posługujący się inicjałami J. G. duchowny warszawski porównywał zanik praktyk w Polsce z podobnym procesem jaki miał miejsce we Francji po wielkiej rewolucji i w całym wieku XIX, i konstatował:

My jesteśmy na drodze do tego samego zjawiska. Kościoły przed wojną przepełnione ludem bywają obecnie przerzedzone. Przed ludnością wiejską otwarły się mnogie widnokręgi nowe, wywołujące jej zainteresowanie i ciekawość, względnie pociągające jej uczucie. Kościół jest już w najlepszym razie jedną $\mathrm{z}$ atrakcji nie jedyną. Przy tym i przeciętny parafianin stał się leniwy i drażliwy, nastrojony jest krytycznie i faszerowany uprzedzeniami przeciw księżom i wierze 9 .

Zdaniem duchownych spadkowi religijności towarzyszył upadek moralności, a oba te zjawiska wzajemnie na siebie oddziaływały. Typową charakterystykę tej nowej sytuacji znajdujemy w referacie dla duchowieństwa ze zjazdu księży diecezji gnieźnieńskiej z 1922 r.:

Ludzie bogobojni i uczciwi patrzą z przerażeniem na zanik życia etycznego jaki zakradł się do naszego społeczeństwa. Sale taneczne, ulice, a nawet domy prywatne stały się widownią niesłychanego upadku moralnego. Świętość węzła małżeńskiego doznaje poniżenia. (...) Chęć zarobkowania bez uczciwej pracy i co za tym postępuje, chęć używania niczym nie skrępowanego ogarnęła wszystkie warstwy społeczeństwa. Czar otaczający życie religijne rozprysł się okrutnie a obelga i oszczerstwo dotykają bezkarnie sługi Boże, co więcej następców Apostołów i Namiestników Chrystusowych ${ }^{10}$.

Inną analizę oddziaływania przemian społecznych na życie religijne wiernych, jak się wydaje zgodną z oceną wielu duchownych, dał piszący o inteligencji wielkomiejskiej ks. S. Margorin:

Inteligencję (...) właśnie to wielkomiejskie życie popędza do jakiegoś niewytłumaczalnego, gorączkowego pośpiechu, do nerwowych nieokreślonych porywów, czego rezultatem jest powierzchowność i płytkość myślowa, dorywczość i brak zgłębienia umysłowego. Hałas, huk, zgiełk, kotłującego się życia wielkomiejskiego, trąbki samochodów, dzwonki tramwajów, głośniki radiowe, egoizm, nietakt, chamstwo i złośliwość sąsiadów, wszystko to szarpie nerwy współczesnego człowieka i pobudza do nierozważnych czynów. Taka atmosfera wpływa ujemnie na stan moralny. Życie zaś religijne człowieka ogranicza się po większej części do przelotnych, szybko przemijających, sentymentalnych afektów ${ }^{11}$.

\footnotetext{
${ }^{8}$ S. Margorin, Stan religijny naszej inteligencji, WAW, 22 (1932) nr 9, s. 343.

${ }^{9}$ J. G., $Z$ teki starego księdza, WAW, 12 (1922) nr 5, s. 111.

${ }^{10}$ Prawidłowa organizacja podstaw diecezjalnej pracy społecznej, WDD, 9 (1922) nr 12, s. 212.

${ }^{11}$ S. Margorin, Stan religijny naszej inteligencji. Dokończenie, WAW, 22 (1932) nr 10, s. 382.
} 
Tęsknota za utraconą idyllą życia w jego tradycyjnych, dawnych formach i przekonanie, że wraz z ich utratą życie religijne stało się zagrożone, często towarzyszyła wypowiedziom księży na temat skutków zmieniających się warunków życia. Warto jednak zauważyć, że był to specyficzny topos, pojawiający się w wypowiedziach duchownych w różnych epokach. Był on przejawem swoistego konserwatyzmu kulturowego właściwego jednak nie tylko dla tej grupy społecznej.

Ks. S. Margorin, w cytowanej wypowiedzi, dostrzegał zachodzący w powojennym społeczeństwie głębszy proces jego laicyzacji, gdy pisał:

dzisiejszy świat mało jest chrześcijański. (...) Bakcyle indyferentyzmu religijnego nurtują w powietrzu współczesnego życia. Inteligencja nasza jest wyraźnie ateistyczną, ani sekciarską, ani bezbożną, ani ofiara sceptycyzmu, tylko obojętną i oziębłą. Jej katolicyzm jest więc bierny, aniżeli czynny; pochodzący nie tyle z przekonania, jak raczej z przesłanek narodowo-tradycyjnych.

Myśl o zanikaniu głębszej religijności przy równoczesnym trwaniu zewnętrznych związków społeczeństwa $\mathrm{z}$ formami religijnymi z pobudek narodowych, powracała w wypowiedziach księży, także biskupów, w całym okresie międzywojennym.

Równolegle do tych pesymistycznych nastrojów, właściwych nie tylko dla starszych duchownych, rozwijał się nurt nadziei na ożywienie religijne narodu polskiego w warunkach odzyskania własnej państwowości. Wyrazem tego może być list episkopatu z tego samego co artykuł ks. S Margorina roku 1934. Jego celem duszpasterskim było mobilizowanie katolików w dziele odnowy życia zbiorowego i indywidualnego:

Odpływa fala pozytywizmu i liberalizmu religijnego. Wśród świeckich coraz częściej spotykamy mężów i kobiety o wybitnym duchu apostolskim. Idea czynu katolickiego przenika szerokie warstwy. Ożywia się tętno życia parafialnego. Miłosierdzie chrześcijańskie dokonuje wielkich rzeczy. Zmienia się oblicze życia katolickiego. Jest ono wyraźniejsze, głębsze. Ogół katolików jest bardziej z hierarchią zespolony więcej solidarny, aktywniejszy, więcej przeniknięty odpowiedzialnością za wiarę i Kościól. A co najlepiej charakteryzuje dzisiejszy katolicyzm to pragnienie uduchowienia i świętości ${ }^{12}$.

Zdaniem biskupów ta przemiana oblicza katolicyzmu w Polsce, wpisywała się w europejski nurt jego odnowy, który, jak sądzili hierarchowie, miał się na nowo stać fundamentem odbudowy społeczeństw i państw europejskich, do czego nawiązywał Pius XI już w 1922 r. w encyklice Ubi arcano Dei. W cytowanym liście pasterskim episkopatu czytamy:

Faktem jest, że w Europie chyli się do upadku nie katolicyzm, ale to co w zamiarach wolnomyślicieli miało być jego spadkobiercą i przeciwieństwem. Bankrutują teorie przez Kościół potępione, a więc marksizm, pozytywizm, liberalizm i sprzeczny z etyką i encyklikami kapitalizm. Ginie fałszywa kultura, wyrosła z przeciwieństwa do nauki Chrystusowej. Natomiast to co katolickie nie upada, lecz odradza się, rośnie, zdobywa ${ }^{13}$.

${ }^{12}$ List pasterski Episkopatu o ducha chrześcijańskiego w Polsce, WAW, 24 (1934) nr 2, s. 51.

${ }^{13}$ Tamże, s. 52. 
W zachodzących po I wojnie światowej negatywnych zmianach społecznych, księża widzieli głównie skutek oddziaływania żywiołów wrogich Kościołowi katolickiemu. Charakterystycznie dla całego środowiska ujął to ks. M. Bielawski, wykładowca gnieźnieńskiego seminarium:

Trzy armie idą na Kościól: masoneria mająca tylko 2 miliony członków, rozporządzająca jednak ogromnymi sumami i przeważającą częścią prasy, z masonerią $\mathrm{w}$ związku socjalizm, trzecia armia idzie zza morza, a idzie w pięciu kolumnach: Metodystów, Episkopalnych, Prezbiterianów, Baptystów, Kwakrów i na dobitkę Hodurowców ${ }^{14}$.

Wzrost działalności sekt protestanckich w okresie bezpośrednio po wojnie budził wśród księży szczególne obawy. Było to bowiem zjawisko stosunkowo nowe i w takim natężeniu nie znane w okresie wcześniejszym. Obawiano się, że słabnąca wiara może sprzyjać porzucaniu katolicyzmu i wiązaniu się z ruchami protestanckimi. Niepokój budziła działalność charytatywna protestantów, która miała zdaniem duchownych na celu przyciąganie do protestantyzmu wiernych znajdujących się w szczególnie trudnej sytuacji materialnej. Zagrożenie uważano za tak istotne, że za konieczne uznał się nim zająć episkopat, który już na zjeździe w Krakowie w 1921 r. wskazywał na niebezpieczeństwa działalności protestantów „maskujących się często działalnością charytatywną i oświatową"15.

Szczególną obawę biskupów budziła działalność stowarzyszenia charytatywnego YMCA, o czym pisali w odezwie ze wspomnianej konferencji mówiąc wprost na czym polega mechanizm tego zagrożenia:

musimy zwrócić uwagę na działanie Stowarzyszenia YMCA, którego filantropijnym zasługom dla naszego kraju wyraziliśmy uznanie już w przeszłym roku, które jednak rozciągając swoją działalność na wychowanie młodzieży, kryje w sobie jedno z najpoważniejszych dla naszej wiary niebezpieczeństw. Stowarzyszenie to założone wśród otoczenia protestanckiego i protestanckim duchem przejęte, nie występuje u nas może wprost zaczepnie przeciw Kościołowi katolickiemu. Głosząc jednak zasadę wychowania w jakimś ogólnym, międzywyznaniowym chrześcijańskim duchu, oswaja naszą młodzież z poglądem o równości i równej wartości wszystkich chrześcijańskich wyznań, zasadę odrzuconą i potępioną przez Kościół katolicki ${ }^{16}$.

Na łamach WAW anonimowy autor w 1922 r. zamieścił wykaz kilku ważniejszych inicjatyw protestanckich z podaniem ich warszawskich adresów, przytoczył nazwy wydawanych przez innowierców czasopism. Przy tej okazji ostrzegał, że w stolicy rozwijały swoją działalność także związki bezwyznaniowe. Ostrzegał, że prowadzą one działalność mającą na celu uznanie gminy bezwyznaniowej:

Zadanie tego związku byłoby jawne i prawomocne wyzwolenie członków od wszelkiego przymusu ze strony Kościołów w zakresie obrządków i świadczeń. Związek bezwyznaniowy zgromadziłby zgodnie zarówno przeciwników religii, jak i tych, których religia wyklucza formy historyczne. Uzyskałby dla nich

\footnotetext{
${ }^{14}$ M. Bielawski, Konieczności duszpasterskie doby obecnej, WDD, 10 (1923) nr 2-3, s. 26.

${ }^{15}$ Ze zjazdu Episkopatu w Krakowie, WDD, 8 (1921) nr 10, s. 188.

${ }^{16}$ Odezwa Episkopatu w sprawie szerzacego się sekciarstwa, WAW, 12 (1922) nr 8-9, s. 157.
} 
świeckie rejestry urodzin, małżeństw, zgonów, umożliwiłby wychowanie bez nauki religii wyznaniowej, składanie w sądzie zeznań bez przysięgi religijnej itp. ${ }^{17}$

Powstanie takiej organizacji uważał za niedopuszczalne i wzywał do przeciwdziałania temu ze strony diecezjalnej komisji do czuwania nad moralnością (consilium a vigilantia).

Słabnąca wiara i religijność wpływały na obniżenie poziomu moralności wiernych. W opinii duchowieństwa zjawiska te wzajemnie się przenikały i warunkowały. Szczególne zagrożenie dla moralności widzieli księża jeszcze od wieku XIX w prasie i literaturze, które nie do końca udawało się podporządkować cenzurze religijnej. Obawy te nasiliły się po I wojnie światowej. W sposób ostry, ale oddający poglądy duchowieństwa $\mathrm{w}$ tym zakresie pisał ks. dr. Z. Baranowski z poznańskiego:

Pornografia zatruwa nam rdzeń narodu, a my zamiast stek plugastwa spalić na średniowiecznym stosie, dysputujemy nieraz o nagości w sztuce i bezradnie zaradczych poszukujemy środków. Wielki odłam literatury i prasy bałamuci nam lud drwinami z religii, lub brakiem zasad moralnych, a my tak skromni jesteśmy, że za prasę szczerze katolicką uważamy tę, która nie zaczepia księży, a o religii milczy $\mathrm{z}$ uszanowaniem ${ }^{18}$.

W podobnym duchu ocenę problemu przedstawił na zjeździe pisarzy katolickich w 1932 r. kard. A. Kakowski:

W imię fałszywie pojętej wolności słowa i prasy toleruje się u nas najbardziej karygodne oszczerstwa i napaści pewnych odłamów prasy na religię katolicką, Stolicę Św., i na Episkopat; przez palce patrzy się na propagandę literatury pornograficznej i sztuk teatralnych ośmieszających katolicyzm, papiestwo i moralność chrześcijańskąa .

W tym samym przemówieniu od uczestników zjazdu pisarzy katolickich, kard. A. Kakowski domagał się ze strony tego związku obrony Kościoła oraz tradycyjnych ideałów religijnych i narodowych przed „napaściami i przewrotną działalnością masonerii i wolnomyślicielstwa, radykalizmu i sekciarstwa, które panoszą się i krzewią w Polsce, korzystając z wybujałej wolności”.

Ze względu na zagrożenie dla moralności w ogień krytyki ze strony księży często wpadały także nowe formy sztuki i rozrywki. Dla przykładu warto przytoczyć, jedną z bardziej powściągliwych w tym zakresie wypowiedź ks. Z. Baranowskiego:

Dalszym źródłem zgorszenia może się stać także teatr lub opera, bądź to przez nieoględny dobór sztuk wystawianych, bądź to przez balety nieraz tak kuse, że dawne baletnice sprzed lat kilkunastu, można by zaangażować jako nauczycielki skromności dla dorastających panienek ${ }^{20}$.

${ }^{17}$ Y., Czuwajmy!, WAW, 12 (1922) nr 5, s. 119.

${ }^{18}$ Z. Baranowski, Katolicyzm wojujacy, czy cierpiacy, WDD, 12 (1925) nr 2, s. 5.

${ }^{19}$ Przemówienie J. E. Kardynała Kakowskiego podczas otwarcia pierwszego ogólnopolskiego zjazdu pisarzy katolickich $w$ Warszawie, WAW, 22 (1932) nr 1, s. 27.

${ }^{20}$ Z. Baranowski, Zatrute studnie, WDD, 15 (1928) nr 4, s. 102. 
Jako istotną okoliczność sprzyjającą upadkowi obyczajów, księża powszechnie wskazywali szerzenie się nowych tańców. Za charakterystyczną w tym względzie możemy uznać wypowiedź ks. I. Adamskiego:

Wolność zebrań i zabaw stała się przyczyną ogromnego rozluźnienia obyczajów. (...) Mania dancingów panująca epidemiczne w całym świecie powojennym, ogarnęła również nasz lud wiejski. Majówki i tańce nocne zaś stały główną okazją zepsucia moralnego naszej młodzieży ${ }^{21}$.

Warto zauważyć, że potępianie nowoczesnych tańców i nieskromnej mody kobiecej, było tematem, który często powracał w nauczaniu Piusa XI, począwszy już od encykliki Ubi arcano Dei.

Ks. I Adamski w dalszej części cytowanego artykułu wskazywał na inne zjawiska, związane z nowymi sposobami spędzania wolnego czasu, stanowiące zagrożenie dla moralności. Były nimi tzw. familienbady, czyli kąpieliska nad rzekami i jeziorami. Ze zgrozą opisywał znane sobie sytuacje panujące w Puszczykowie nad Wartą i nad jeziorem Góreckim:

Brzegi i najbliższa okolica jeziora góreckiego w sezonie kąpielowym są jednym wielkim publicznym zamtuzem. (...) Letnicy poznańscy rekrutujący się przeważnie z kół młodzieży kupieckiej i szkolnej, młódź męska i żeńska pospołem, rozbierają się nad brzegami jeziora, także przy ścieżkach publicznych, kąpią się wspólnie i urozmaicają sobie zabawę indiańskimi tańcami w kostiumach kąpielowych. (...) Na bezpłatne to widowisko ściągają tłumy młodzieży wiejskiej z całej okolicy. (...) Można sobie wystawić jakie zgorszenie rozpusta grójecka szerzy wśród całej naszej okolicy ${ }^{22}$.

Księża powszechnie byli przekonani, że za działaniami na rzecz upadku wiary i moralności stały organizacje masońskie, tradycyjnie wrogie Kościołowi katolickiemu. W sposób typowy dla poglądów duchowieństwa w całym okresie międzywojennym pisał o tym ks. S. Żelazowski: „Żyjemy w okresie ostrej walki o ideały katolickie. Przeciwko Kościołowi występuje masoneria i dobrze zorganizowane różne partie radykalne nie przebierające w środkach"23. Podobnie wyrażał się duchowny kielecki ks. Z. Pilch:

Wolnomyśliciele i masoneria to zawołani propagatorzy niezależnej moralności. (...) Obyczajowe niezależnictwo przypuściło już gwałtowny szturm, aby zdobyć młode pokolenie. Masoneria będąca jego intelektem znalazła rychło bastion najważniejszy i przygotowała zamach na szkoły i nauczycielstwo. Sekunduje jej w tym większość naszych ciał ustawodawczych ${ }^{24}$.

Radykalnie w kwestii możliwych form reakcji katolików na działalność masonerii wypowiadał się anonimowo duchowny poznański:

Kompromisu w tej sprawie nie ma. Masoneria zwalczająca objawienie, chrześcijaństwo, a ze szczególną zaciętością Kościół katolicki, masoneria potępio-

\footnotetext{
${ }^{21}$ I. Adamski, Odrodzenie rodziny katolickiej w parafiach wiejskich, WDD, 13 (1926) nr 5, s. 7.

${ }^{22}$ Tamże, s. 9.

${ }^{23}$ S. Żelazowski, Kurs duszpasterski w Warszawie, WAW, 19 (1929) nr 11, s. 406.

${ }^{24}$ Z. Pilch, Przeciwdziatanie niezależnej moralności, WDD, 16 (1929) nr 2, s. 30.
} 
na wielokrotnie z wyżyn Stolicy Piotrowej, jest dla katolika błędem i złem, z którym trzeba walczyć bezwzględnie, aż do zwycięstwa ${ }^{25}$.

Tradycyjnie niepokój księży budził wzrost wpływów socjalistycznych. Pojęciem tym często określano zbiorowo zarówno socjalistyczne ruchy robotnicze, jak i radykalne organizacje chłopskie. O ile socjalizm wśród robotników był zjawiskiem znanym, z którym księża walczyli długo przed wojną, to rozwój radykalnych ruchów na wsiach szczególnie w Poznańskiem, budził zaniepokojenie. Przykładem może być fragment drukowanego na łamach WDD niepodpisanego referatu ze zjazdu księży w Gnieźnie:

Ale i wśród robotników rolnych zaszły nader poważne zmiany. Za czasów rządów zaborczych robotnicy rolni stanowili warstwę ludzi najmniej oświeconych i najwięcej potulnych. Do życia organizacyjnego i społecznego byli mało przygotowani. Od tej chwili walka pomiędzy kapitałem a pracą przenosi się na spokojną, uczciwą i zacną wieś. Dawniejsze stosunki przypominające sielankę zniknęly bezpowrotnie. Do robotnika rolnego dociera agitator socjalistyczny oraz wysłannik komunistyczny ${ }^{26}$.

W zgodnej opinii księży zmiany społeczne zachodzące w nasilającej się postaci od przełomu XIX i XX w, a szczególnie spotęgowane w okresie powojennym, wpływały niekorzystnie na rodzinę i jej katolicki rozwój. Pisał o tym w sposób typowy ks. B. Jarosz: ,

$\mathrm{Z}$ ubolewanie stwierdzamy pewne rozprzężenie a nawet pewien upadek życia naszych rodzin. Księża najlepiej zdają sobie sprawę jak daleko posunęło się zło (...). Zmniejszyła się troska rodziców o dusze dzieci, o ich wychowanie, brak współdziałania rodziców z Kościołem, ze szkołą. Dzieci nie wynoszą z domu dostatecznego zasobu zasad wiary i moralności, odporność ich wobec zła się zmniejsza, szerzy się wśród nich demoralizacja, przestępczość rośnie. Autorytet rodziców ucierpiał znacznie. Jest rozdźwięk między rodzicami a dziećmi, nie ma posłuchu, a za to nawet pewne lekceważenie rodziców ${ }^{27}$.

Dalej ten sam autor, na dowód jak głęboko sięgały w rodzinach demoralizujące zmiany przytaczał list pewnej matki do córki, która wyjechała za chlebem do Francji. W liście tym „matka jej opisuje szczęście, jakie spotkało jej młodszą córkę, bo dziś bogaty pan wziął ją sobie na utrzymanie, to jest jako nałożnicę". Matka zachęca więc córkę do powrotu, ,gdyż i jej zamiast pracy we Francji, może się podobna kariera przytrafić" 28 .

Szukając przyczyn takich postaw autor zauważał, że tkwią one w „duszach ludzkich” i narzekał: „Bezmyślność, brak zasad, wygoda, żądza użycia opanowały społeczeństwo powojenne, a razem z nim także nasze rodziny". Obok takiego tradycyjnego, moralizatorskiego podejścia zdobył się jednak na dostrzeżenie pewnych społecznych i gospodarczych przyczyn, tkwiących w dokonujących się procesach społecznych, które sprzyjały upadkowi rodziny. Były nimi: „dzisiejsze zewnętrzne warunki życia takie jak drożyzna, brak zarobków, nędza mieszkanio-

\footnotetext{
${ }^{25}$ X. B. Niebezpieczeństwo masońskie, WDD, 15 (1928) nr 11, s. 324.

${ }^{26}$ Prawidłowa organizacja podstaw diecezjalnej pracy społecznej, WDD, 9 (1922) nr. 12, 210.

${ }^{27}$ B. Jarosz, Odnowienie rodziny katolickiej, WDD, 12 (1925) nr 10-12, s. 34.

${ }^{28}$ Tamże, s. 35.
} 
wa". Przy tej okazji krytykował także narastające, właściwe dla stosunków kapitalistycznych, podejście pracodawców do wynagradzania pracowników, które nie uwzględniało „zobowiązań pracownika wobec rodziny”. Negatywnie pisał o tym zjawisku:

ojciec pracujący zarabia na ogół mniej aniżeli mu potrzeba na zaspokojenie najważniejszych, najistotniejszych potrzeb rodziny.(...) Ten stan nie zachęca do zakładania rodzin, prowadzi do sztucznego obniżania liczby dzieci i z dużą szkodą dla życia rodzinnego, do dodatkowego zarobkowania matek ${ }^{29}$.

Autor wskazywał na mechanizm łączący zachodzące niekorzystne zmiany społeczne, które wywierając ekonomiczny nacisk na rodzinę wpływał negatywnie na postawy religijne:

Nie można się dziwić, że w rodzinie przytłoczonej troską o chleb powszedni, brakiem zarobków żywiciela, lub nędzą mieszkaniową, panuje atmosfera cięż$\mathrm{ka}$, że nie ma pogodnego wesela, lecz przeciwnie szerzy się niezadowolenie $\mathrm{i}$ bunt. Gdy na takie podłoże padnie jad agitacji socjalistycznej, z hasłami walki klas, nienawiści klasowej, wówczas wzbudzi u rodziny uczucie krzywdy, nienawiści do społeczeństwa i rozgoryczenia przeciw Bogu ${ }^{30}$.

Dobro rodziny i jej religijny rozwój tradycyjnie znajdowały się w polu oddziaływania duszpasterskiego i troski kleru. Księża podkreślali jej niezastąpioną rolę $\mathrm{w}$ procesie wychowania religijnego młodego pokolenia. Nie dziwi zatem fakt negatywnej oceny zjawisk, jakie mogłyby rodzinie zagrażać. Poglądy księży jeśli chodzi kształt rodziny, jej funkcjonowanie czy podział ról, były tradycyjne. Jako charakterystyczną w tym zakresie można zacytować wypowiedź ks. B. Jarosza:

Rodzina jest najlepszym, można rzec jedynym środowiskiem wychowawczym. Szkoła, Kościół i życie budują już tylko na fundamencie wychowania rodzinnego. (...) $\mathrm{Z}$ rodziny czerpie społeczeństwo swoje siły. Spokojna i pogodna atmosfera jest szczególnie dla ojca, pracującego zawodowo poza domem, tą cichą przystanią, która go wita po całodziennych trudach, przyciąga i przykuwa do siebie. Przypomina ona tak ojcu, jak matce ich zaszczytne posłannictwo, do którego zostali powołani dla dobra dusz swych dzieci, dla sprawy Kościoła i społeczeństwa ${ }^{31}$.

Księża często wskazywali na niebezpieczeństwa jakie niesie zmiana tradycyjnego modelu rodziny i jako przykład wskazywali na upadek życia rodzinnego do jakiego doszło w komunistycznej Rosji. Potępiano tamtejszą łatwość rozwodów, wzrost liczby aborcji, czy wpływ państwa na wychowanie młodego pokolenia. Przed niebezpieczeństwem zmian modelu i celów społecznych rodziny wielokrotnie przestrzegał także episkopat. Charakterystyczna w tym względzie może być jego odezwa z 1934 r. „Rodzina i w Polsce zaczyna niedomagać na następstwa tego światopoglądu, który odtrącając prawo Boże, zapatruje się na rodzinę pod kątem widzenia indywidualnego użycia, bez względu na zasady etyczne, na społeczne zadania i dobro ogólne" ${ }^{32}$. W ocenie biskupów zasadę tak pojętego szczę-

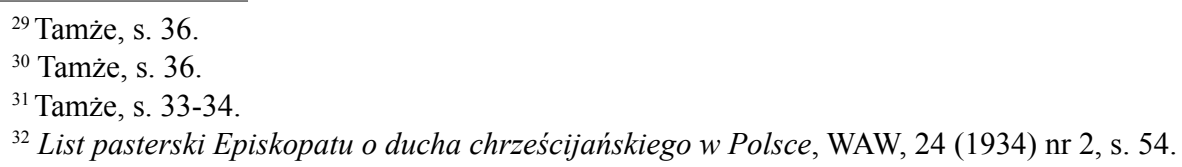


ścia osobistego jako celu małżeństwa propagują te kręgi społeczeństwa, które z zasad liberalizmu przejęły „spuściznę bezbożnej etyki społecznej”. Powodowało to „niezrozumienie dla katolickiego obyczaju małżeńskiego, a nawet wyszydzanie wierności małżeńskiej”. W dalszej części odezwy biskupi przestrzegali: „Rodzina nie jest domem zabawy i uciechy, lecz powołaniem do obowiązku, do wzniosłej misji, do ofiary i trudu".

Taka wizja rodziny wypływała z tradycji Kościoła, umocnionej w XIX-wiecznych encyklikach papieskich. Wydanie przez Piusa XI w 1930 encykliki Casti connubii, przypomniało i wzmocniło to nauczanie, dając także episkopatowi oręż $\mathrm{w}$ zwalczaniu potępionych praktyk w polskim społeczeństwie i systemie prawnym. Walka o katolicki charakter instytucji małżeństwa, zwalczanie rozwodów i tzw. świadomego planowania rodziny, stanowiła w okresie międzywojennym jeden z głównych sporów na linii Kościół - państwo ${ }^{33}$.

W związku z kryzysem rodziny i jej funkcji religijnego wychowawcy, wzrastało w tym zakresie znaczenie szkoły. Edukacja młodego pokolenia zawsze była w polu zainteresowania i oddziaływania Kościoła, chociaż w okresie zaborów było ono znacznie ograniczone państwową polityką edukacyjną. W zachodzących w niepodległej Polsce przemianach systemu edukacyjnego księża dostrzegali wiele niebezpieczeństw. Najważniejszym było odrzucenie przez państwo w organizacji systemu szkolnictwa zasady oparcia go na kryterium wyznaniowym. Znaczenie szkoły wyznaniowej, o której wprowadzenie w Polsce Kościół walczył w okresie międzywojennym, polegało na oparciu całego procesu edukacyjnego na wartościach chrześcijańskich i korelacji treści nauczania wszystkich przedmiotów w duchu katolickim.

Niebezpieczeństwa przyjętego przez państwo modelu szkoły wskazywał w sposób reprezentatywny dla poglądów polskiego duchowieństwa m.in. poznański ksiądz podpisujący się inicjałami St. C.:

Co znaczą te trzy lekcje religii $\mathrm{w}$ tygodniu i trzykrotna spowiedź $\mathrm{w}$ roku, jeśliby w szkołach naszych wychowawcami dzieci byli pedagodzy łączący w sobie tendencyjność w nauczaniu z sekciarską wprost nienawiścią, gdy chodzi o katolicyzm, jeśliby używali podręczników dających dawki trucizny acz w małych dozach, ale często i mogących przez to podsunąc zwątpienia i torować drogę wolnej, niezależnej myśli ${ }^{34}$.

Katolicka wizja oczekiwań w stosunku do organizacji systemu szkolnictwa i innych form wychowania młodzieży, została sformułowana już na początku okresu międzywojennego. Znajdujemy ją m.in. w postanowieniach zjazdu katolickiego w Poznaniu z 1920 r.:

Wobec niebezpieczeństw jakie szkoła międzywyznaniowa kryje w sobie dla zdrowego wychowania ducha młodzieży i wobec tej prawdy, że tylko szkoła wyznaniowa, daje młodzieży niezmącony pogląd na życie i świat, domagamy się aby ustawa zapewniła polskiej szkole powszechnej i średniej charakter narodowy i wyznaniowy ${ }^{35}$.

${ }^{33}$ K. Krasowski, Episkopat katolicki w II Rzeczypospolitej, Warszawa/Poznań 1992, s. 191-198.

${ }^{34}$ St. C., Zatrute źródła nauki, WDD, 8 (1921) nr 8-9, s. 164.

${ }^{35}$ Ze zjazdu katolickiego w Poznaniu, WAW, 10 (1920) nr 12, s. 251-252. 
W opinii zjazdu nie tylko szkoła, ale także pozaszkolne organizacje skupiające młodzież winny uwzględniać kryteria wyznaniowe:

Uznając pierwiastek religijny za zasadniczy czynnik w wychowaniu młodzieży zwracamy się do wszystkich katolickich stowarzyszeń i związków młodzieży $\mathrm{z}$ apelem aby w pracy swojej nad młodzieżą uwzględniały w wybitnym stopniu moment religijny. (...) zwracamy się z prośbą do władz państwowych, aby w ramach swoich kompetencji współpracowały nad dziełem religijnego odrodzenia młodzieży, poruczając katolikom obowiązki wychowania i nauczania młodzieży katolickiej ${ }^{36}$.

Zagrożenia dla właściwego katolickiego rozwoju młodzieży widziano również w koedukacji oraz nieodpowiednich kwalifikacjach, w tym moralnych, nauczycieli. Na tym tle dochodziło do znacznych napięć między episkopatem a związkiem zawodowym nauczycieli szkół powszechnych. Przykładem zaostrzenia konfliktu może być reakcja na wystąpienia jego działaczy na zjeździe w 1930 r. W wydanej w związku z tym odezwie biskupi pisali m.in.:

Zdawać by się powinno, że zjazd (...) poświęci wszystkie chwile i narady swoje rozważaniu (...) czym by można rozbudzić w młodych tych duszach, nauczycielowi przez rodziców powierzonych, miłość do Stwórcy i do życia nadprzyrodzonego; jak nastroić piękne struny pobożności dziecka, aby przez całe dalsze życie grały hymn wdzięczności dla Boga, za jego niezliczone dary, na duszę nieśmiertelną zlewane. Tymczasem jak ze sprawozdań ze zjazdu tego wynika, wygłaszano na nim postulaty tak sprzeczne z wymaganiami zdrowego wychowania, tak nienawistne w stosunku do religii, do Kościoła i jego sług, że wzbudziły w społeczeństwie powszechne uczucie zgrozy i lęku, o dusze naszej młodzieży szkolnej ${ }^{37}$.

W roku 1929 papież Pius XI wydał encyklikę o chrześcijańskim wychowaniu młodzieży Divini illius Magistri, w której przypomniał znaczenie szkoły katolickiej. Nie wprowadzała ona co prawda w tym zakresie nowych treści, ale podobnie, jak Casti connubi w odniesieniu do małżeństwa, przypominała katolikom naukę Kościoła o wychowaniu. Obie encykliki wskazywały wagę omawianych obszarów życia społecznego. Obie w istotny sposób wzmacniały kierunki działania katolików i duszpasterzy w międzywojniu w społeczeństwach europejskich. Dążenia do realizacji ich zaleceń wyznaczały także kierunki odnowy polskiego katolicyzmu, według modelu właściwego dla rozwoju Kościoła powszechnego w okresie między soborami Watykańskim I i Watykańskim II ${ }^{38}$.

Księża chętnie ukazywali niebezpieczeństwa niesione przez nowe zjawiska społeczne i kulturowe w perspektywie odwiecznej walki dobra ze złem. Typowym przykładem może być wypowiedź ks. J. Prądzyńskiego:

Jesteśmy więc po prostu świadkami wyścigu światopoglądów, którego ostatnią nagrodą jest dusza narodu. Myśli katolickiej rzuca kłody i głazy pod nogi

${ }^{36}$ Tamże.

${ }^{37}$ Odezwa Episkopatu Polski w sprawie antyreligijnych wystapień na zjeździe Zwiazku Nauczycieli Szkół Powszechnych w Krakowie w lipcu 1930 r., WAW, 20 (1930) nr 8-9, s. 281.

${ }^{38}$ J. Kłoczowski, Dzieje chrześcijaństwa polskiego, t. 2, Paris 1991, s. 95-115; M. Rogalski, Producenci margaryny. Marian Zdziechowski i polski modernizm katolicki, Kraków 2018, s. 27-28. 
popierane ze względów politycznych i fanatycznych sekciarstwo zagraniczne. Duszę katolicką osłabia i nadwątla rozwiązłość moralna w zastraszający sposób wgryzająca się przez literaturę, sztukę, obyczaj towarzyski i modę, w podstawy moralne dzisiaj już gęstych warstw ludu. Myśl chrześcijańską rozcieńcza stale, celowo, usilnie jakiś panteizm, torujący drogę religii humanitaryzmu, wspierany przez ideologię komunizmu. A wszystko to razem zmierza do wyłączenia Boga z królestwa bożego, aby je przekształcić w wielki ateizm ${ }^{39}$.

W poglądach wielu księży spotykamy charakterystyczne podejście historiozoficzne zawierające wizję dziejów cywilizacji europejskiej, jako stałego upadku, powodowanego odchodzeniem od wierności zasadom religii chrześcijańskiej. Typowa w tym względzie może być wypowiedź ks. W. Karasiewicza:

Dopóki światopogląd chrześcijański w wiekach średnich, całe życie publiczne i po wielkiej części prywatne w swoich karbach utrzymywał, nie było tak jaskrawych jak obecnie i prawie, że powszechnych nadużyć. Przewrót religijny (w 16 w.), który obdarzył ludzkość nowoczesnym racjonalizmem, liberalizmem, socjalizmem, komunizmem, dawał człowiekowi coraz większą wolność, nie zdając sobie sprawy, albo zamykając na to oczy, że człowiek nie dorósł do takiej swobody. Rozbito społeczeństwo chrześcijańskie i zniszczono hamulce, jakie miała jednostka w ówczesnym porządku świata. Skutki są opłakane: wyrasta coraz silniejszy egoizm, szukający wszędzie tylko swego zadowolenia goniący za rozrywkami ${ }^{40}$.

Takie podejście księży do zmian zachodzących w społeczeństwie i ich ocena nawiązywały do tradycyjnego ich przedstawiania, jakie kształtowało się w XIX wieku w dobie sporu między rozwijającymi się nowoczesnymi państwami, nowoczesnymi formami organizacji społeczeństw i narodów, w okresie dynamicznego rozwoju kapitalizmu ${ }^{41}$. Opór katolicyzmu przed tymi zmianami najpełniej był wyrażany w encyklikach papieży od Grzegorza XVI w 1. poł. XIX w. aż do Piusa X w początkach XX w. Charakteryzował się ono obawami przed wieloma nowymi zjawiskami społecznymi, które postrzegano, jako wymierzone w tradycyjny świat wartości religijnych, podlegający celowemu niszczeniu przez siły wywrotowe.

Od czasów Leona XIII takiemu kierunkowi przemian starano się przeciwstawić katolicki projekt rozwoju stosunków społecznych, który uwzględniałby nadprzyrodzone cele człowieka, a w szczególności zbawienie duszy. Ideałem do którego należało dążyć było kierowanie się w życiu indywidualnym, społecznym i państwowym wartościami chrześcijańskimi, jako fundamentalnymi i niezmiennymi, jedynie gwarantującymi właściwy rozwój społeczeństw. Do budowania takich religijnych fundamentów pokoju i takiego układania relacji w społeczeństwach i między państwami wzywał również Pius XI w swoich encyklikach, począwszy od pierwszej z 1922 r. Ubi arcano Dei.

${ }^{39}$ J. Prądzyński, Wyścig, WDD, 12 (1925) nr 5, s. 6.

${ }^{40}$ W. Karasiewicz, Zabawy i rozrywki, WDD, 17 (1930) nr 2, s. 39.

${ }^{41}$ M. Janowski, Matzeństwo z rozsądku: katolicyzm i nowoczesność w XIX w., „Kwartalnik Historyczny", 122 (2015) nr 4, s. 678-685. 
Duchowni polscy mieli świadomość, że prosty powrót do sytuacji społecznej sprzed I wojny światowej, czy do jeszcze bardziej odległej przeszłości, jest niemożliwy. Celem jaki stawiał tak przed księżmi, jak i wiernymi świeckimi episkopat od pierwszych lat niepodległości był taki kierunek odbudowy odradzającej się Polski, aby zrealizować w niej wskazywane przez papieży, ideały społeczeństwa i państwa katolickiego. Bardzo wyraźnie pisał o tym abp. A. Kakowski w liście do duchowieństwa i wiernych już w 1919 r.

Polska powinna być i pozostać katolicką. (...) Państwo bez religii umiera i ty narodzie polski umarłbyś, skorobyś wyrzucił religię z domów, rodzin, gmin i z państwa. (...) Religia katolicka jest religią olbrzymiej większości, że bezwzględnie przysługiwać jej winien tytuł religii panującej i zagwarantowane być powinny wszystkie jej prawa ${ }^{42}$.

Abp A. Kakowski zdawał sobie sprawę z trudności realizacji tego celu w warunkach wielonarodowej i wielowyznaniowej Polski po 1918 r. W cytowanym liście zawarł stwierdzenia, które jego zdaniem miały rozwiać obawy przedstawicieli innych wyznań, jakie realizacja katolickiego projektu mogła wśród nich zrodzić:

My katolicy w poczuciu świętej prawdy naszego Kościoła, rządzimy się zasadą miłości względem każdego człowieka dobrej woli i nikomu krzywdy nie wyrządzimy. Idea religii katolickiej w Polsce panującej, powyższym zasadom wcale się nie sprzeciwia. Owszem stwierdzamy, że zdrowo pojęta idea religii panującej łączy się nierozerwalnie z tolerancją dla innych wyznań ${ }^{43}$.

Księża nie tylko dostrzegali zagrożenia niesione przez powojenne zmiany społeczne, ale w sytuacji odrodzenia niepodległego państwa widzieli istotną możliwość moralnej odnowy narodu. W tym celu formułowali pozytywne projekty, których realizacja miała zapewnić narodowi polskiemu rozwój religijny w tradycyjnym dla niego związku z katolicyzmem. Projekty te nawiązywały do programów odnowy społeczeństw formułowanych przez papieży na przełomie XIX i XX w, a rozwijanych w okresie międzywojennym przez Piusa XI w czasie jego długiego pontyfikatu.

Od samego początku duchowni zwrócili uwagę na długofalowy charakter procesu budowania Polski katolickiej i wiązali to $\mathrm{z}$ koniecznością wychowania nowego pokolenia wiernych o silnym i pogłębionym związku z katolicyzmem. Poważną przeszkodą $\mathrm{w}$ realizacji postawionego celu, na którą często wskazywano, był niski poziom uświadomienia religijnego starszego pokolenia wiernych. $\mathrm{Za}$ ten stan księża zgodnie obwiniali przemiany intelektualne i społeczne okresu pozytywizmu. Starsze pokolenie, szczególnie elity świeckie społeczeństwa i narodu, uważali księża za dotknięte negatywnymi skutkami pozytywizmu, który prowadził do ich odchodzenia od wiary, a w konsekwencji także osłabienia wiary i religijności w całym społeczeństwie. Kontynuowanie pozytywistycznych poglądów starszego pokolenia uznawane było za sprzeczne $\mathrm{z}$ wielkimi celami katolickiej odnowy narodu polskiego.

${ }^{42}$ Arcybiskup Metropolita Warszawski do duchowieństwa i ludu wiernego, WAW, 9 (1919) nr 5, s. 121-123.

${ }^{43}$ Tamże, s. 123. 
Jak głęboko w świadomości duchowieństwa tkwiło przekonanie o długofalowych i negatywnych skutkach pozytywizmu dla religijności Polaków, może świadczyć to, że często do tak sformułowanej myśli powracał nawet kard. A. Kakowski. W roku 1929 przemawiając na zjeździe organizacji młodzieży akademickiej „Odrodzenie” mówił m.in.:

młodzież akademicka epoki pozytywistycznej, nieomal za dogmat miała zasady: bez Boga, walka z religią, rozbrat z Kościołem (...). Walka starszego pokolenia z Bogiem wyjałowiła dusze, osuszyła jedno z ożywczych źródeł życia narodó $\mathrm{w}^{44}$.

Kardynał wielokrotnie przeciwstawiał pozytywizm starszego pokolenia romantyzmowi współczesnej młodzieży, romantyzmowi, którego istotnym elementem był powrót do religii. Pisał o tym jeszcze w 1938 r. w ostatnim swoim liście do młodych:

kiedy młodzież XIX wieku, wychowana w atmosferze materializmu i pozytywizmu, wyższości materii nad duchem wykluczała religię z życia prywatnego i publicznego, ze szkół zwłaszcza wyższych, większość dzisiejszej młodzieży akademickiej z dumą i radością wywiesiła sztandar z hasłami panowania ducha nad materią, duszy nad ciałem; wzięła z głębokim przekonaniem religię za podstawę życia indywidualnego i społecznego, i państwowego (...) uznała wiarę $\mathrm{w}$ życie pozagrobowe wieczne za naczelną zasadę postępowania ludzkiego zarówno w dziedzinie spraw osobistych jak i publicznych ${ }^{45}$.

Zdaniem duchowieństwa wpływy ideologii pozytywistycznej legły także u podstaw kładzionych po I wojnie światowej politycznych fundamentów odradzającego się państwa. Brak pogłębionej świadomości katolickiej, znajomości celów jakie wyznaczał Kościół organizacji życia społecznego, wpłynął m.in. na kształt wyznaniowych zapisów w konstytucji z $1921 \mathrm{r}$. Tak pisał na ten temat anonimowy ksiądz sprawozdawca ze zjazdu katolickiego w Bydgoszczy z sierpnia $1921 \mathrm{r}$.

Jak potrzebną rzeczą jest uświadomienie katolickie wykazał choćby występ p. wiceministra dr. Wachowiaka, który (...) za oczywisty dowód opieki, jaką rząd otacza katolicyzm, podał artykuł 117 konstytucji, opiewający, że wśród równouprawnionych wyznań katolicka religia zajmuje naczelne stanowisko. Z pewnością nie zła wola, ale brak uświadomienia katolickiego sprawił, że pan wiceminister jako dowód życzliwości rządu dla Kościoła wysunął to, co wedle naszych pojęć sprzeciwia się postulatom katolickim, bo katolikom nie wolno traktować wszystkich religii jako równorzędnych. Prawda jest i może być tylko jedna ${ }^{46}$.

Kilka lat później, w roku 1926, inny duchowny poznański ks. S. Durzyński już w o wiele ostrzejszych słowach oceniał postanowienia konstytucji marcowej:

${ }^{44}$ Przemówienie J. E. Ks. Kardynała Kakowskiego na inauguracji kongresu „Odrodzenia”, WAW, 19 (1929) nr 11, s. 397.

${ }^{45}$ List pasterski J. Em. Kardynała Aleksandra Kakowskiego do młodzieży, WAW, 28 (1938) nr 7-8, s. 338.

${ }^{46}$ Dwa zjazdy katolickie, WDD 8 (1921) nr 8-9, s. 157. (autor artykułu błędnie podaje numer artykułu konstytucji marcowej: 117 zamiast $114-\mathrm{GB})$. 
Liberalny charakter artykułu 114 konstytucji polega przede wszystkim na tym, że pojmując religię jako rzecz prywatną wyznawców, (...) raczej nie uznaje wcale charakteru odrębnego religii katolickiej, wyznacza jej tylko, wśród konglomeratu równouprawnionych wyznań honorem praecedentiae, coś w rodzaju prima inter pares. Hasło rozdziału Kościoła od państwa jest nie tylko, antykatolickie, antykościelne, ale sprzeciwia się także prawu przyrodzonemu, jest ono tak jak i formuła o wolności wyznań, w aspiracjach swoich bardzo podejrzane $^{47}$.

Katolicką wizję stosunków kościelno-państwowych będących celem działań katolików w odrodzonym państwie polskim przedstawiano często i przy różnych okazjach. W sposób charakterystyczny zaprezentowana została w postulatach zjazdu katolickiego w Warszawie z września 1921 r. W rezolucjach zjazdu stwierdzono:

(...) konieczność ukształtowania całego życia prywatnego i publicznego w myśl ideałów katolickich oraz potrzebę zabezpieczenia Kościołowi całkowitej wolności i niezależności od władz świeckich we wszystkich dziedzinach życia kościelnego. (...) Zjazd uważa za obowiązek władzy państwowej zabezpieczenie poszanowania prawa kościelnego przez katolików z pomocą egzekutywy państwowej szczególnie w dziedzinie prawa małżeńskiego, rodzicielskiego, szkolnego, moralności publicznej, święcenia niedzieli ${ }^{48}$.

Ważnym narzędziem w dziele długofalowego rozwijania i pogłębiania wśród wiernych świadomości religijnej była Akcja Katolicka. Jej idea kształtowała się w Kościele powszechnym już od czasów pontyfikatu Piusa X, ale ostateczny kształt ruchowi temu został nadany przez Piusa XI. Świadomość potrzeby istnienia tej organizacji w Kościele polskim narastała powoli i była poprzedzona licznymi próbami poszukiwania najwłaściwszych dla niej form organizacyjnych ${ }^{49}$. Ostatecznie statut polskiej Akcji Katolickiej zatwierdził papież w 1930 r. W drugiej połowie lat trzydziestych ruch nabrała powszechnego charakteru, a jego oddziaływanie zaczęło przynosić pierwsze, wyraźne efekty. Wybuch II wojny światowej i jej konsekwencje w znacznej mierze położyły kres temu kierunkowi i tym formom odnowy religijności polskiego społeczeństwa jakie kształtowały się w okresie międzywojennym.

Przytoczone w niniejszym artykule wypowiedzi księży z okresu międzywojennego, mimo, ich sondażowego charakteru, zarysowują - wymagające dalszych badań - intelektualne tło wielopłaszczyznowych działań podejmowanych przez duchowieństwo polskie w celu katolickiej odnowy społeczeństwa okresie II RP. W działaniach tych za punkt wyjścia przyjmowano stan religijny i moralny społeczeństwa po wojnie. Nie ograniczano się jednak w jego ocenie jedynie do prostego tłumaczenia negatywnych zjawisk zakończonym konfliktem światowym, szukano jego głębszych przyczyn, tkwiących we wcześniejszych kierunkach rozwoju polskiego społeczeństwa w okresie zaborów. Formułowane długofalowe cele odnowy i konkretne zadania w ich ramach pozostawały w zgodzie z tradycyj-

\footnotetext{
${ }^{47}$ S. Durzyński, ,, Czuwajcie”, WDD, 13 (1926) nr 11, s. 25.

${ }^{48}$ Dwa zjazdy katolickie, WDD, 8 (1921) nr 8-9, s. 160.

${ }^{49}$ K. Jeżyna, Akcja Katolicka w II Rzeczypospolitej, Lublin 1996, s. 29-44.
} 
nym nauczaniem Kościoła. W związku z tym, mimo ich zbieżności z nauczaniem Piusa XI nie były one tylko jego skutkiem, ale pozostawały w głębszym nurcie katolickiego programu odnowy społeczeństw europejskich po negatywnie ocenianych z punktu widzenia religii, przemianach jakie zaszły w długim wieku XIX. Wpływ encyklik Piusa XI i wypowiedzi ważnych urzędników kurii rzymskiej, $\mathrm{i}$ ich różnorakie korelacji z momentami zwrotnymi w dziejach międzywojennego polskiego katolicyzmu, wymagają dalszych pogłębionych badań. Pod względem doktrynalnym, wizji świata i społeczeństwa, nauczanie papieskie w okresie międzywojennym kontynuowało tendencje z przełomu XIX i XX w. Pius XI mocno nawiązywał jednak do nowej społecznej, gospodarczej i politycznej sytuacji jaka powstała po zakończeniu I wojny światowej. O wiele bardziej precyzyjnie niż w poprzednim stuleciu przedstawił katolicki program organizacji społeczeństwa masowego, który stanowił coraz bardziej pełną i spójną alternatywę dla podobnych propozycji, jakie pojawiały się w tamtym czasie ze strony socjalizmu, komunizmu i faszyzmu. Nauczanie papieskie chociaż skierowane do całego Kościoła w pierwszym rzędzie, podobnie jak w wieku XIX, było odpowiedzią na problemy narastające głównie, choć nie wyłącznie, w społeczeństwach Europy Zachodniej i w tamtych wspólnotach katolickich. Analiza adaptacji tego nauczania do warunków rozwoju społeczeństwa polskiego (np. radykalizacji młodego pokolenia $\mathrm{w}$ drugiej połowie lat 30 . XX wieku przy wyznaczanym mu miejscu w programie odnowy religijnej polskiego społeczeństwa), mimo prowadzonych w tym zakresie badań, wciąż daje wiele możliwości dla nowych ujęć i interpretacji.

W tym kontekście jednym $z$ dalszych postulatów badawczych może być próba uchwycenia ewentualnych różnic i podobieństw w ujmowaniu omawianych zmian społecznych, wskazywaniu ich przyczyn i sposobów przeciwdziałania w ujęciu różnych pokoleń księży. Czy, a jeśli to jakie są różnice w tym zakresie między duchowieństwem wykształconym w okresie rozbiorów a opuszczającym seminaria już w okresie niepodległej Polski. Im bliżej 1939 r. tym bardziej rosła grupa księży którzy większość, lub całą swoją edukację, w tym przed seminaryjną, odebrali w II RP. Jak wpływało to na ich podejście do omawianych zagadnień? Ważne jest też poszerzenie bazy źródłowej o wypowiedzi duchowieństwa z Galicji i wykorzystanie innego rodzaju tekstów pozostawionych przez księży (kazania, nauki rekolekcyjne, artykuły popularyzatorskie skierowane do różnych grup społecznych).

Do ważnych wniosków może też prowadzić podjęcie badań interdyscyplinarnych, uwzględniających w większym stopniu wyniki badań innych nauk nad zmianami $\mathrm{w}$ społeczeństwie polskim $\mathrm{w}$ tamtym okresie. Czy wypowiedzi duchownych miały charakter ogólnoduszpasterski i niejako „ponadczasowy”, czy może ich nasilenie, sposób ujęcia i proponowane rozwiązania były powiązane $\mathrm{z}$ nasilającymi się problemami generowanymi aktualnymi przemianami społeczeństwa, które niepokoiły duszpasterzy? Niniejszy artykuł jako sondażowy nie wyczerpuje omawianych zagadnień, mam jednak nadzieję, że wskazał na istniejący w tym zakresie potencjał badawczy. 


\section{BIBLIOGRAFIA}

\section{Źródła}

Adamski I., Odrodzenie rodziny katolickiej w parafiach wiejskich, „Wiadomości dla Duchowieństwa", 13 (1926) nr 4, s. 4-7.

Adamski I., Odrodzenie rodziny katolickiej w parafiach wiejskich, „Wiadomości dla Duchowieństwa", 13 (1926) nr 5, s. 6-12.

Arcybiskup Metropolita Warszawski do duchowieństwa i ludu wiernego, „Wiadomości Archidiecezjalne Warszawskie”, 9 (1919) nr 5, s. 121-124.

Baranowski Z., Katolicyzm wojujący, czy cierpiacy, „Wiadomości dla Duchowieństwa”, 12 (1925) nr 2, s. 3-6.

Baranowski Z., Zatrute studnie, „Wiadomości dla Duchowieństwa”, 15 (1928) nr 4, s. 101-105.

Bielawski M., Konieczności duszpasterskie doby obecnej, „Wiadomości dla Duchowieństwa", 10 (1923) nr 2-3, s. 25-29.

Durzyński S., ,Czuwajcie”, „Wiadomości dla Duchowieństwa”, 13 (1926) nr 11, s. 21-27.

Dwa zjazdy katolickie, „Wiadomości dla Duchowieństwa”, 8 (1921) nr 8-9, s. 154-160.

J., G., Z teki starego księdza, „Wiadomości Archidiecezjalne Warszawskie”, 12 (1922) nr 5, s. 110-112.

Jarosz B., Odnowienie rodziny katolickiej, „Wiadomości dla Duchowieństwa”, 12 (1925) nr 10-12, s. 33-41.

Karasiewicz W., Zabawy i rozrywki, „Wiadomości dla Duchowieństwa”, 17 (1930) nr 2, s. 37-41.

List pasterski Episkopatu o ducha chrześcijańskiego w Polsce, „Wiadomości Archidiecezjalne Warszawskie", 24 (1934) nr 2, s. 49-60.

List pasterski J. Em. Kardynała Aleksandra Kakowskiego do młodzieży, „Wiadomości Archidiecezjalne Warszawskie”, 28 (1938) nr 7-8, s. 334-356.

Margorin S., Stan religijny naszej inteligencji, „Wiadomości Archidiecezjalne Warszawskie", 22 (1932) nr 9, s. 343.

Margorin S., Stan religijny naszej inteligencji. Dokończenie, „Wiadomości Archidiecezjalne Warszawskie", 22 (1932) nr 10, s. 382-385.

Marlewski F., Kazania w zastosowaniu do dzisiejszych czasów i prądów, „Wiadomości dla Duchowieństwa", 9 (1922) nr 12, s. 217-223.

Odezwa Episkopatu Polski w sprawie antyreligijnych wystapień na zjeździe Zwiazku Nauczycieli Szkół Powszechnych w Krakowie w lipcu 1930 r., „Wiadomości Archidiecezjalne Warszawskie", 20 (1930) nr 8-9, 280-282.

Odezwa Episkopatu w sprawie szerzacego się sekciarstwa, „Wiadomości Archidiecezjalne Warszawskie", 12 (1922) nr 8-9, s. 156-158.

Pilch Z., Przeciwdziałanie niezależnej moralności, „Wiadomości dla Duchowieństwa”, 16 (1929) nr 2, s. 30-34

Prawidłowa organizacja podstaw diecezjalnej pracy społecznej, „Wiadomości dla Duchowieństwa”, 9 (1922) nr 12, s. 209-216.

Prądzyński J., Wyścig, „Wiadomości dla Duchowieństwa”, 12 (1925) nr 5, s. 5-8.

Przemówienie J. E. Ks. Kardynała Kakowskiego na inauguracji kongresu „, Odrodzenia”, „Wiadomości Archidiecezjalne Warszawskie”, 19 (1929) nr 11, s. 396-398.

Przemówienie J. E. Kardynała Kakowskiego podczas otwarcia pierwszego ogólnopolskiego zjazdu pisarzy katolickich $w$ Warszawie, „Wiadomości Archidiecezjalne Warszawskie", 22 (1932) nr 1, s. 22-29. 
St. C., Zatrute źródła nauki, „Wiadomości dla Duchowieństwa”, 8 (1921) nr 8-9, s. 161164.

X. B., Niebezpieczeństwo masońskie, „Wiadomości dla Duchowieństwa”, 15 (1928) nr 11, s. $324-325$.

Y., Czuwajmy!, „Wiadomości Archidiecezjalne Warszawskie”, 12 (1922) nr 5, s. 118-119.

Zamojski W., Potrzeba czasu, „Przegląd Diecezjalny”, 5 (1917-1918) nr 1, s. 11-16.

Ze zjazdu Episkopatu w Krakowie, „Wiadomości dla Duchowieństwa”, 8 (1921) nr 10, s. $188-189$.

Ze zjazdu katolickiego w Poznaniu, „Wiadomości Archidiecezjalne Warszawskie”, 10 (1920) nr 12, s. 251-252.

Żelazowski S., Kurs duszpasterski w Warszawie, „Wiadomości Archidiecezjalne Warszawskie", 19 (1929) nr 11, s. 400-407.

\section{Opracowania}

Bergmann O., Pomiędzy konserwatywnym tradycjonalizmem a nowoczesnościa. Bezpośredni i pośredni wplyw duchowieństwa katolickiego na procesy modernizacji spolecznej i gospodarczej Drugiej Rzeczypospolitej, w: Metamorfozy spoleczne, t. 5. Religia a społeczeństwo Drugiej Rzeczypospolitej, red. T. Stegner, Warszawa 2013, s. 83-105.

Bibliografia katolickich czasopism religijnych $w$ Polsce 1918-1944, red. Z. Zieliński, Lublin 1981.

Janowski M., Małżeństwo z rozsądku: katolicyzm i nowoczesność w XIX w., „Kwartalnik Historyczny”, 122 (2015) nr 4, s. 657-699.

Jeżyna K., Akcja Katolicka w II Rzeczypospolitej, Lublin 1996.

Kościól katolicki w Polsce 1918-1990. Rocznik statystyczny, red. L. Adamczuk, W. Zdaniewicz, Warszawa 1991.

Kłoczowski J., Dzieje chrześcijaństwa polskiego, t. 2, Paris 1991.

Krasowski K., Episkopat katolicki w II Rzeczypospolitej, Warszawa/Poznań 1992.

Rogalski M., Producenci margaryny. Marian Zdziechowski i polski modernizm katolicki, Kraków 2018. 


\section{THE CATHOLIC CLERGY IN THE FACE OF SOCIAL CHANGES IN THE INTERWAR PERIOD: AN OUTLINE OF RESEARCH ISSUES}

\section{Summary}

The article presents the views of the Catholic clergy of the interwar period on selected aspects of the changes taking place in contemporary Polish society regarding religiosity, morality, the family, and the upbringing of younger generations. This analysis, which is preliminary and survey-oriented, discusses only some aspects of these issues in the context of the interwar Catholic renewal movements. The article is based on clergymen's statements - primarily from the two former annexed territories: Prussian and Russian - included in the pages of two monthly magazines (influential and opinion-forming in the clerical milieu): Wiadomości dla Duchowieństwa published in Poznań, and Wiadomości Archidiecezjalnych Warszawskich published in Warsaw.

Key words: the Catholic Church; the clergy; the interwar period; the Second Republic of Poland; social changes 